Article

\title{
An Exploration of Social License to Operate (SLTO) Measurement in the Port Industry: The Case of North America
}

\author{
Bruno Moeremans * and Michaël Dooms
}

Citation: Moeremans, B.; Dooms, M. An Exploration of Social License to Operate (SLTO) Measurement in the Port Industry: The Case of North America. Sustainability 2021, 13, 2543. https://doi.org/10.3390/su13052543

Academic Editor: Vítor Caldeirinha

Received: 29 January 2021

Accepted: 20 February 2021

Published: 26 February 2021

Publisher's Note: MDPI stays neutral with regard to jurisdictional claims in published maps and institutional affiliations.

Copyright: (c) 2021 by the authors. Licensee MDPI, Basel, Switzerland. This article is an open access article distributed under the terms and conditions of the Creative Commons Attribution (CC BY) license (https:/ / creativecommons.org/licenses/by/ $4.0 /)$.
Department of Business, Vrije Universiteit Brussel, B-1050 Brussels, Belgium; michael.dooms@vub.be

* Correspondence: bruno.moeremans@vub.be

\begin{abstract}
In this paper, we develop exploratory research to improve the understanding of actual practices applied in the port industry relating to local communities' perception measurement and public engagement, aiming at maintaining and fostering relationships with local communities. The application of such practices would allow port managing bodies to improve their strategic alignment with the needs and requirements of their local communities. To this end, we distributed a survey to North American port managing bodies and terminal operators. The survey, answered by 37 respondents, follows a structure defined by critical elements affecting stakeholder perceptions and acceptability in relation to a project or an ongoing business activity. The results disclose differences in social license to operate measurement and public engagement practices between port managing bodies and terminal operators. Furthermore, follow-up interviews were conducted with eight port managing bodies in order to capture the value added and the barriers to engage with local communities. Finally, the study enables benchmarking possibilities both within the sample and on a global level, giving an indication and assessment of the respondents' competitive positions regarding stakeholder perceptions, communication, and engagement practices, and the steps to be taken in order to strengthen any strategic and competitive state.
\end{abstract}

Keywords: social license to operate; public engagement; local communities; ports

\section{Introduction}

Port expansion projects and the (re)development of the port area have distanced the port cluster from the city and its local communities [1-4]. In addition to the potential benefits port clusters provide to the global economy, their activities and expansions can be the generator of undesired negative externalities [5]. Moreover, the economic benefits generated by port clusters on the port area and their adjacent communities are uncertain [6]. Communities' knowledge and awareness regarding negative externalities and perceived limited regional economic benefits generated by port clusters have improved. This has led to demands for standstill on port developments and reduced port activities in certain regions $[7,8]$. In the recent past, several social conflicts have emerged as a consequence of port expansion projects and activities. European examples, to name a few, include The Port of Antwerp with the Deurganckdok project or the Port of Rotterdam with Maasvlakte 2 [3,8-10]. The sustainability and social legitimacy or social license to operate (SLTO) of a port cluster can be at stake if the bargaining power of local communities and the social dimension of ports' activities is neglected [11]. The influence of local communities can reach far beyond what can be expected. Sustainable practices can be directly and indirectly influenced by them [12-16]. Moreover, the social acceptability from local communities or social license to operate is a driver of change in sustainable port performance [3].

Port managing bodies have increased their consideration for the interests of local communities as a consequence [10,17], leading to a change in their strategic behavior $[18,19]$. Port planning has been adjusted towards a more stakeholder inclusive process $[6,7,11,19]$. New coordinating functions within port managing bodies have emerged, such as the role 
of community or cluster managers aimed at solving conflicts with the local community to foster social acceptability and a social license to operate $[17,20,21]$.

In this context, stakeholder management practices and communication strategies by port managing bodies are necessary to manage the concerns of local communities [10,22-24]. Accordingly, public involvement is crucial to forge a positive perception of the port cluster and move forward towards sustainable development [25]. Public participation and community outreach are important mechanisms to strengthen the social license to operate. When applied in a consistent and effective way, these practices have the potential to address tangible and intangible social impacts, hence contributing to social development [26-28]. For that reason, for port managing bodies to tackle harmful social issues, strengthen sustainable activities and create a competitive advantage, the assessment and measurement of their social license to operate is meaningful. The real value of such measurement exercise lies, as argued for mainstream companies [29], in its comparison with the overall sustainability "reality" score of a port cluster assessed through, e.g., sustainability reporting [30]. As a consequence, strategical decision makers can collect additional information regarding critical areas of sustainability by performing this exercise [30] since reporting on triple bottom line performance does not capture the essence of a social license to operate [8].

A number of port clusters have on an ad hoc basis engaged in social license to operate measurement practices in the past (e.g., Rotterdam, Antwerp, and Hamburg), albeit without much public transparency and further structural application nowadays [30]. Users' perspectives, stakeholders' perception and levels of satisfaction are among the most neglected issues by port managing bodies, at least from a (public) reporting perspective [31]. In order to ensure the future application of public engagement mechanisms and emphasize the importance of the social license to operate and its measurement in the port industry, further research is therefore required. Our contribution aims to provide a deeper understanding of the social license to operate concept within the port industry. This research finds its origins in the few theoretical and empirical contributions made in the port management literature concerning public engagement practices, the social license to operate, and its quantification and formal disclosure.

To bring this research further, we believe that an explorative step is needed to deepen the understanding of actual practices applied by port managing bodies and terminal operators related to local communities' perception measurement and engagement practices, aiming at maintaining and fostering a social license to operate. For this purpose, we designed a survey in partnership with Green Marine, an environmental certification program for the North American marine industry, and disseminated it amongst their members. Additionally, we conducted follow-up in-depth interviews with port managing bodies, all members of Green Marine. These interviews gave insights into the value associated to reaching out to local communities, as well as the potential barriers. By doing so, we build further on previous findings of Cahoon [23] and Parola et al. [32] regarding public engagement practices and innovative marketing strategies of port managing bodies, and Brooks and Pallis [31] in relation to perception measurement of ports' stakeholders. Dooms $[8,30]$ and Voyer and van Leeuwen [28], discussing the broader subject of social license to operate in a port industry context, constitute an additional basis for our research. Finally, this research is a reflection of the broader subject considering both user perception and stakeholder satisfaction as an indicator of port performance (see Dooms [8], Dooms et al. [9] and Deforche et al. [33]).

This paper is structured as follows. Section 2 provides an overview of social license to operate research performed in port management literature, with a broader view on the marine environment literature. Section 3 outlines the materials used and methods applied for the research. Section 4 provides an overview of the main results generated from the disseminated survey and conducted interviews with the North American port industry. Section 5 illustrates and discusses the main results. Finally, Section 6 concludes with implications for decision makers and future research. 


\section{Literature Review: The Social License to Operate in the Marine Environment and Port Management Literature}

The "social license to operate" concept was first applied in the mining sector. At first, the mining industry and its operations were largely accepted by the public as a provider of minerals and metals, and more particularly as an unconditional provider of wealth to society. However, the emergence of environmental issues and conflicts with local communities led to a negative reputation and an undesirable mining industry [34]. During the 1990s, a shift occurred in the public perception of the generated environmental impacts and social performance of the industry. Subsequently increasing the societal and environmental pressure in the mining industry, leading to the emergence and application of the "social license to operate" (SLTO) [35]. Joyce and Thomson [36] performed a first attempt to define the term social license to operate. The authors defined the term as the approval and acceptance given by the society and local community stakeholders to organisations' activities and infrastructure projects, enabling these organisations to proceed with their operations. Over the years, the term spread out to other industries and business as a consequence of similar encountered social impacts and issues as in the mining industry $[35,37,38]$.

In the marine environment literature, Cullen-Knox et al. [39] investigated to which extent decisions made by the Australian government on the use and the impact of the marine environment and its resources is influenced by the SLTO. Kelly et al. [40] reviewed the use of the term social license to operate in the marine environment literature. In a following step, Kelly et al. [41] conducted a perception study of marine stakeholders in Tasmania and investigated the practical application of the social license to operate for marine protected areas. Voyer and van Leeuwen [28] inquired the legitimacy of Blue Economy activities, an ocean based economic growth model, based on interviews, a survey and a workshop with actors of the ocean business community. Their research defines a conceptual model that explores which particular local community stakeholders grant a social license (community of place or community of practice), which local communities' concerns have an impact on a social license (tangible or intangible impacts), and how private organisations foster a social license (public relations, education, consultation, and participatory planning). The authors conclude that Blue Economy sectors operationalize SLTO through technological applications and one-way stakeholder engagement strategies.

While the term social license to operate has frequently been used in the port management literature, few empirical researches have been conducted regarding the SLTO subject in this field. In this context, Ircha [42] summarized different initiatives conducted by Canadian and international port managing bodies. By doing so, the author stresses the importance for Canadian and international port clusters to seek for a social license to operate. Within the port sustainability literature, Dooms [8] performed exploratory research relating to the social license to operate in port clusters. His research defines a conceptual framework enabling the assessment of triple bottom line performance against the strength of a social license to operate for port managing bodies. However, such conceptual framework is only considered useful in case an effective standardized and harmonized measurement method for the social license to operate is available. Further conceptual and empirical development is suggested as a consequence, since a quantified social license to operate indicator (or set of indicators) could contribute to improved triple bottom line reporting.

Considering the need to effectively measure the social license to operate, Thomson and Joyce [43] made an attempt to quantify the acceptability and approval stemming from local communities in the mining sector. Different theoretical levels for the social license to operate were generated. Thomson and Boutilier [34] refined the different levels in such a manner that item generation was possible. The models suggested by Thomson and Joyce [43] and Thomson and Boutilier [34] lay the foundations for an effective quantification of the different levels and criteria of the SLTO. At final, Thomson and Boutilier [44] gave birth to the social license to operate measurement model. 
Within the port management literature, limited research focuses on the importance of quantifying stakeholders' and local communities' perceptions and acceptability $[8,30]$. Deforche et al. [33] indicate that, in the context of a perception-based research mandated by the Port of Antwerp, the quantification of local communities' experiences is important for and desired by local communities themselves. The authors conclude that this practice would allow port managing bodies to assess their social license to operate in a first step, to disclose it under the form of an indicator in a second step, which in turn, would contribute to strengthen their social license to operate on the basis of transparency in a final step. Dooms $[8,30]$ emphasizes the strategic utility of such model and assessment exercise for and by ports. However, assessment practices of local communities' perception and social license have not been broadly applied in the port industry [30]. An overview of the academic literature related to the social license to operate in the marine environment and the port management literature is provided in Appendix A.

As a consequence, this research paper aims to gather more in-depth insights regarding the current mechanisms used by the port industry for the assessment of local communities' perceptions and social license to operate, and more generally, the public participation or engagement mechanisms applied, influencing any relationship with local communities. Furthermore, the aim of this research is to understand whether the perception of local communities is considered or can be considered by the port industry as an indicator of performance next to other operational, environmental and financial performance indicators. This research is performed for the case of North America. The North American port industry, in line with other world regions, is faced with opposition to port development in many locations (such as Vancouver and Los Angeles). Therefore, it is an interesting case to develop with a potential to replicate and expand the research to a global level.

\section{Materials and Methods}

A close collaboration was set up with Green Marine building on common interests regarding gathering insights into the social license to operate subject in the port industry. As a widely adopted environmental certification program in North America with a stakeholder-inclusive governance structure (see http:/ / www.green-marine.org (accessed on 10 April 2020) and Walker [45]), Green Marine was selected as the most suitable partner for this research. Its membership base shows a broad geographical spread in the United States of America and Canada, and a wide variety of ports and terminals in terms of size, location (proximity to urban areas or nature areas; coastal versus river ports), and types of traffics handled.

Therefore, an online questionnaire on public engagement and social license to operate measurement practices in the North American port industry has been designed in collaboration with Green Marine and disseminated amongst their program participants. Interviews with port managing bodies, all members of Green Marine, have subsequently been performed in order to gather specific information concerning the potential value added and barriers to reach out to local communities.

\subsection{Survey Design and Implementation}

In this section, information on Green Marine and the design, structure and implementation of the survey is disclosed.

\subsubsection{Green Marine}

Green Marine is a voluntary environmental certification program for and by the North American marine industry addressing environmental and social sustainability issues through a fixed set of 12 performance indicators. The environmental and social performance of every single participant is determined on a yearly basis through self-evaluation. The initiative aims to reduce the environmental footprint of the North American marine industry through the obtained performance results of each participant and the formulation of concrete actions as a consequence. Program participants are shipowners, ports, 
terminals, Seaway corporations and shipyards, geographically located in Canada and the United States of America (see http:/ / www.green-marine.org (accessed on 10 April 2020) and Walker [45]). During February 2019, two weeks were spent at Green Marine's premises in Quebec City (Canada) for the initial conception of the survey. Further review and validation of the questionnaire was performed by experts within the Green Marine's member network, and finally tested by Green Marine's employees. The finalized survey was distributed during June 2019 throughout July 2019 through SurveyMonkey, an online survey software, as this was the preferred means of the Green Marine network. Participation to the survey was voluntary. The retrieved results have subsequently been treated confidentially and anonymously.

\subsubsection{Survey Sample and Respondents}

Out of Green Marine's program participants, 50 are categorized as ports and Seaways, 71 as terminals and shipyards, and 37 as shipowners (http://www.green-marine.org (accessed on 10 April 2020). For the convenience of this research paper, ports have been renamed as port managing bodies, terminals as terminal operators and Seaways as Seaway administrations. Based on the nature of performed activities by shipowners, i.e., not related to infrastructure development or operations, it was decided to exclude these members as survey recipients. In total, 121 participants of the Green Marine initiative formed our population for the survey. Accordingly, one participation to the survey was allowed per participant. At final, 42 responses have been collected, corresponding to a return rate of $35 \%$. However, after review with Green Marine, three responses were excluded from the collected results as a consequence of two multiple responses by different persons within one organization and one uncompleted survey (total nonresponse). In total, 20 port managing bodies, 17 terminal operators, one Seaway administration and one shipyard participated to the survey. Nevertheless, since the response rate of Seaway administrations (one answer) and shipyards (one answer) were low, we decided to not retain their respective responses as a consequence of a lack of representativeness in our results, leading to a total of 37 responses or a return rate of $31 \%$.

Furthermore, it has to be noted that a number of respondents failed to provide a response to one or more questions, which can be defined as item nonresponse [46]. Different methods to deal with such nonresponse items exist [47]. A correct way of handling an item nonresponse is through deletion of participants with missing data in the survey leading to a reduction of sample size $[48,49]$. A complete case analysis, and more specifically an available-case analysis, would be a judicious method to deal with item nonresponses in this particular case. Nevertheless, this analysis can lead to inconsistent estimates and judgments when comparisons are made between the frequencies of different subsamples [50]. As a consequence, in order to not jeopardize and bias the validity of the survey and specifically the questions where a phenomenon of item nonresponse is absent, we decided to simply display and disclose the missing and blank values per questions as "No answer". By doing so, the relative frequencies of the different answers over the different questions have been calculated using the number of survey participants as a denominator (contrary to the number of provided responses/non-blank responses per question), allowing for consistency and comparison over the whole survey. As a matter of transparency, the numbers of "No answer" have subsequently been disclosed per question, where appropriate.

\subsubsection{Survey Structure}

Our survey was structured and divided into four parts. The first part gathers general information on the survey participants. Information has been collected on the respondents port activities (as a port managing body or terminal operator), preferred language (French or English), yearly handled tonnage, number of full-time equivalents, and finally, proximity to an urban area. This information is helpful in sight of a benchmarking exercise (e.g., port managing bodies versus port terminals). The second part of the survey focuses on the definition of local community stakeholders. Respondents were given the choice to 
define their local community stakeholders based on their unique situation. Next, the third part aims to gather information concerning public participation mechanisms applied by the North American port industry. Several public participation mechanisms have been proposed through closed-ended questions. However, open-ended questions allowed the respondents to formulate the applied public participation mechanisms depending on their unique situation. At final, the last part of the survey questions the respondents on the application of perception and social license to operate measurement mechanisms. Furthermore, it assesses whether the North American port industry considers the perception of local communities as a performance indicator.

An exploratory methodology has been applied and used for the design and structure of questions relating to public participation mechanisms in the third part of the survey, as will be described in the next section. However, no dedicated methodology or framework has been used for respectively part one, two, and four of the survey, given its emerging nature. General exploratory questions were formulated for these respective parts.

\subsubsection{An Exploratory Methodology for the Third Part of the Survey on Public Engagement}

Increased international involvement of the public in the activities and decisions of policy-setting bodies, public, and private organisations, has led to an increasing number of mechanisms allowing for public participation. To shed light on the imprecise definition of terms in the literature around public participation, three key concepts have been defined by Rowe and Frewer [51]: public communication, public consultation, and public participation. Each concept encompasses different public engagement mechanisms based on the nature and flow of information between an exercise sponsor (i.e., the Green Marine survey respondents) and participants or the public (i.e., the local community stakeholders as defined by the Green Marine survey respondents) and their effectiveness to engage. Accordingly, Rowe and Frewer [51] proposed a typology of public engagement mechanisms that could be used as a helpful tool for our research.

Consequently, the third part of our survey and subsequent analysis of results have been structured in accordance with the proposed model of Rowe and Frewer [51]. Each individual public engagement mechanism, proposed through closed-ended questions or generated as an answer from open-ended questions in our survey, has been categorized under one of the aforementioned public engagement concepts (see Appendix B). The mechanisms for public engagement classified under each individual concept can differ in terms of fairness [52,53]. Fairness is defined as the extent to which a certain engagement exercise or mechanism has been conducted in an honest manner, and is perceived as such by those involved in the participation process [51]. For the purpose of this explorative research, we assume that all the proposed and generated public engagement mechanisms in our survey are fair to some extent. The fairness assumption allows us to connect the various public engagement mechanisms to the concept of social license to operate.

As such, fairness is a key factor in the framework of social license to operate creation and obtention by Moffat and Zhang [54]. The theoretical framework proposed by these authors consists of four factors (impacts on social infrastructure, contact quantity, contact quality, and procedural fairness) affecting and influencing the perception that local communities have of an organization's activities. Of these four factors, procedural fairness, defined as the extent to which individuals perceive that their voices have been heard and taken into consideration for later use and decision-making, has the greatest positive impact on the creation and obtention of a social license. As a consequence, we intuitively combine both models of Rowe and Frewer [51] and Moffat and Zhang [54], and assume, in an explorative step, that the proposed and generated participation mechanisms from our survey possess a certain degree of (procedural) fairness, subsequently contributing to a social license to operate. However, an analysis of the extent to which the different mechanisms contribute to the creation of a social license to operate is beyond the scope of this research. 


\subsubsection{Data Analysis}

In total, 18 questions were formulated with regards to public engagement and social license to operate mechanisms in the North American port industry. The survey was composed of open-ended and closed-ended questions. SPSS was used in order to establish the absolute and relative frequencies of responses to closed-ended questions. Two questions were formulated using a 7-point Likert-Scale allowing the respondents to specify their level of (dis)agreement for a series of proposed answers. Graphical representations of the retrieved answers were made using Microsoft Excel. Open-ended questions and their respective answers were subsequently clustered within certain categories or themes in order to facilitate the analysis of gathered results.

\subsection{Interviews}

A total of 10 port managing bodies, and members of Green Marine, were contacted for further in-depth interviews. At final, 8 port managing bodies responded positively to our request. Semi-structured in-depth interviews were conducted by means of telephone conversation of approximately one hour each. The interviews were held from August 2019 to September 2019. Questions relating to the value added and barriers of reaching out to local communities were formulated and asked. The choice for semi-structured interviews allowed for flexibility in the addressed questions and provided answers [55]. The provided answers have been manually transcribed and clustered according to different themes allowing us to draw several general conclusions regarding the subject of the performed interviews.

\section{Results}

Under this section the different results for the different areas of the research are described.

\subsection{General Information about the Respondents}

General information regarding the respondents' language, full time equivalents (FTEs), handled tonnage in 2018, and immediate vicinity with an urban area is disclosed in Table 1.

Table 1. General information on respondents.

\begin{tabular}{|c|c|c|c|c|c|c|c|}
\hline & & \multicolumn{2}{|c|}{ Port Managing Body } & \multicolumn{2}{|c|}{ Terminal Operator } & \multicolumn{2}{|c|}{ Total } \\
\hline & & $\mathbf{N}$ & N\% & $\mathbf{N}$ & $\mathrm{N} \%$ & $\mathbf{N}$ & $\mathrm{N} \%$ \\
\hline \multirow{2}{*}{ Language } & English & 14 & $70 \%$ & 8 & $47 \%$ & 22 & $59 \%$ \\
\hline & French & 6 & $30 \%$ & 9 & $53 \%$ & 15 & $41 \%$ \\
\hline Total & Total & 20 & $100 \%$ & 17 & $100 \%$ & 37 & $100 \%$ \\
\hline \multirow{4}{*}{ FTEs } & 0 to 10 & 3 & $15 \%$ & 1 & $6 \%$ & 4 & $11 \%$ \\
\hline & 10 to 50 & 8 & $40 \%$ & 3 & $18 \%$ & 11 & $30 \%$ \\
\hline & 50 to 100 & 3 & $15 \%$ & 2 & $12 \%$ & 5 & $14 \%$ \\
\hline & More than 100 & 6 & $30 \%$ & 11 & $65 \%$ & 17 & $46 \%$ \\
\hline Total & Total & 20 & $100 \%$ & 17 & $100 \%$ & 37 & $100 \%$ \\
\hline \multirow{6}{*}{ Tonnage 2018} & Not applicable & 0 & $0 \%$ & 2 & $12 \%$ & 2 & $5 \%$ \\
\hline & $\begin{array}{l}\text { Less than } \\
500,000 \text { tonnes }\end{array}$ & 3 & $15 \%$ & 1 & $6 \%$ & 4 & $11 \%$ \\
\hline & $\begin{array}{c}500,000 \text { to } \\
5 \text { million tonnes }\end{array}$ & 7 & $35 \%$ & 9 & $53 \%$ & 16 & $43 \%$ \\
\hline & $\begin{array}{l}5 \text { million to } \\
25 \text { million tonnes }\end{array}$ & 2 & $10 \%$ & 2 & $12 \%$ & 4 & $11 \%$ \\
\hline & $\begin{array}{l}25 \text { million to } \\
100 \text { million tonnes }\end{array}$ & 6 & $30 \%$ & 2 & $12 \%$ & 8 & $22 \%$ \\
\hline & $\begin{array}{c}\text { More than } \\
100 \text { million tonnes }\end{array}$ & 2 & $10 \%$ & 1 & $6 \%$ & 3 & $8 \%$ \\
\hline
\end{tabular}


Table 1. Cont.

\begin{tabular}{|c|c|c|c|c|c|c|c|}
\hline & & \multicolumn{2}{|c|}{ Port Managing Body } & \multicolumn{2}{|c|}{ Terminal Operator } & \multicolumn{2}{|c|}{ Total } \\
\hline & & $\mathbf{N}$ & $\mathbf{N} \%$ & $\mathbf{N}$ & N\% & $\mathbf{N}$ & $\mathrm{N} \%$ \\
\hline Total & Total & 20 & $100 \%$ & 17 & $100 \%$ & 37 & $100 \%$ \\
\hline \multirow{2}{*}{$\begin{array}{c}\text { Immediate vicinity } \\
\text { of urban area }\end{array}$} & Yes & 17 & $85 \%$ & 15 & $88 \%$ & 32 & $86 \%$ \\
\hline & No & 3 & $15 \%$ & 2 & $12 \%$ & 5 & $14 \%$ \\
\hline Total & Total & 20 & $100 \%$ & 17 & $100 \%$ & 37 & $100 \%$ \\
\hline
\end{tabular}

A total of 37 responses have been collected from the disseminated survey amongst Green Marine's port managing bodies (PM) and terminal operators (TO). Accordingly, 20 responses from port managing bodies and 15 responses from terminal operators were gathered, respectively accounting for $54 \%$ and $46 \%$ of provided responses. (Terminal operators correspond both to cargo and passenger terminal operators. In total, 15 cargo terminal operators and 2 passenger terminal operators participated to the survey.) A majority of port managing bodies performed the survey in English (70\%). Nevertheless, the English respondents amongst terminal operators are a minority $(47 \%)$. Correspondingly, $30 \%$ of port managing bodies and $53 \%$ of terminal operators filled in the questionnaire in French. The number of full-time equivalents is unevenly distributed amongst the different port managing bodies participating to the survey. The highest share $(40 \%)$ of port managing bodies has 10 to 50 FTEs within their organization. The majority of terminal operators $(65 \%)$ has more than 100 FTEs employed. Regarding the handled traffic volume in 2018, port managing bodies and terminal operators handling an approximate volume from 500,000 tonnes to 5 million tonnes are strongly represented amongst the collected responses. A total of 8 respondents, from which six port managing bodies (30\%) and two terminal operators (12\%) handled 25 million to 100 million tonnes in 2018. (Two terminal operators indicated not having handled cargo in 2018. These two responses correspond those of two passenger terminal operators.) Finally, $85 \%$ of port managing bodies and $88 \%$ of terminal operators are located within, next to or in the immediate vicinity of an urban area.

\subsection{Local Community Stakeholders}

The respondents were asked to identify various stakeholders that could be considered part of their local communities. Nine different stakeholders have been proposed to the survey participants through a close-ended question. A 7-level Likert-Scale allowed the participants to specify their level of consideration for the different proposed stakeholders (from 1 (=not considered) to 7 (=highly considered)). Nevertheless, the respondents where not restricted to the proposed items, the possibility to provide an answer through an open-ended question was enabled. Figure 1 provides a graphical representation of the different stakeholders to consider, and their respective relative frequency as being highly considered (a score from 6 to 7 ) by the respondents.

The results disclose that a majority of port managing bodies and terminal operators highly consider the different proposed stakeholders, with the exception of the local media. Nevertheless, differences in relative frequencies are present and disclosed. In line with the respondent's geographical vicinity with an urban area, residents in the port's or company's surroundings are highly considered as local community stakeholders by port managing bodies $(90 \%)$ and terminal operators $(94 \%)$. Port managing bodies, respectively, highly consider port's or company's clients $(80 \%)$, local community partners $(70 \%)$, external business owners in the port's or company's surroundings $(65 \%)$, port's or company's suppliers $(60 \%)$, provincial/state or national government $(60 \%)$, indigenous people (55\%), and non-governmental organisations (55\%). Terminal operators, respectively, highly consider provincial/state or national government (76\%), indigenous people (71\%), external business owners in the port's or company's surroundings $(65 \%)$, local community partners $(65 \%)$, port's or company's clients $(65 \%)$, non-governmental organisations $(53 \%)$, 
and port's or company's suppliers (53\%). The largest differences in relative frequencies of highly considered stakeholders between port managing bodies and terminal operators are noted for indigenous people, provincial/state or national government, and port's or company's clients, with a respective difference of $16 \%, 16 \%$, and $15 \%$.

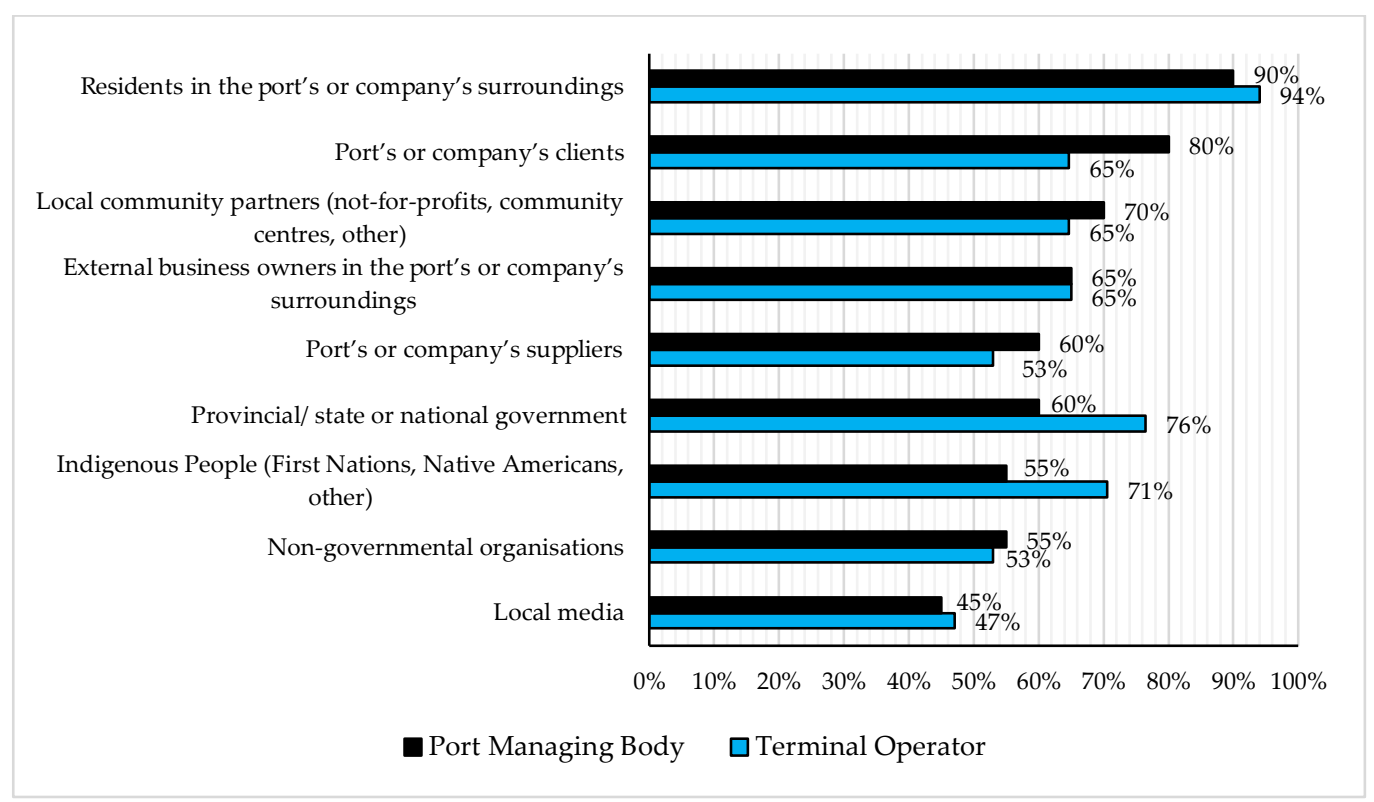

Figure 1. Relative frequencies of local community stakeholders indicated as highly considered (score from 6 to 7 ).

\subsection{Public Engagement}

Respondents were questioned on the different public engagement means they use and apply in order to obtain and strengthen a social license to operate, following the generic public engagement concepts as defined by Rowe and Frewer [51]: public communication, public consultation, and public participation.

\subsubsection{Public Communication}

Following the diversity of existing public communication means, the survey participants were interrogated with regard to the application of technology-based communication tools and the content of subsequent provided information. These tools imply, in a majority of cases, a one-way communication stream from the port managing bodies and terminal operators to their respective local communities [51].

Fifty-five percent $(55 \%)$ of port managing bodies and $59 \%$ of terminal operators claimed to have a website dedicated to local communities. Still, a remaining $40 \%$ of port managing bodies and $35 \%$ of terminal operators lack a website aimed at informing local communities on the respondents' activities and further impacts. Interaction opportunities through the use of social media accounts is popular amongst port managing bodies $(85 \%)$ and terminal operators $(65 \%)$. Social media represents the favored mean of communication of the respondents. The public acknowledgment of a publicly available strategic plan is a common practice amongst port managing bodies $(65 \%)$ but not frequently applied by terminal operators $(12 \%)$. Regarding the disclosure of a publicly available sustainability report, an environmental report or a corporate social responsibility report, $55 \%$ of port managing bodies engage in this exercise. Nevertheless, terminal operators tend to disclose such information and public reports to a lesser extent (41\%). However, the disclosure of social and environmental impacts seems to be enforced and favored through websites, since respectively $60 \%$ of port managing bodies and $53 \%$ have a dedicated website page about sustainability, corporate social responsibility, and/or local communities. Newsletters aimed at informing the local communities are not very used in comparison to other communication 
tools, used respectively by $35 \%$ of port managing bodies and $29 \%$ of terminal operators. The least popular communication tool, indicated by the respondents in a few cases, is represented by a TV or YouTube channel. Finally, one port managing body reported to disclose a land use plan to their external stakeholders and local communities. Based on the above, results show that a diversity of public communication tools is used by the respondents in order to reach out to local communities.

Whilst the enumerated tools potentially represent a low level of interaction between the concerned actors, the respondents were further asked whether they engage in the following practices: financial support of local community initiatives, the organisation of workshops, port, or company open days and a port or company visitor/information center open to the general public. Accordingly, a higher level of interaction between the concerned actors is expected as a consequence of the use of these practices. However, we still considered these practices as regular mechanisms of public communication, aiming to create brand awareness and educate the community regarding the port cluster activities. A large majority, $82 \%$ of the respondents, respectively, $75 \%$ of port managing bodies and $89 \%$ of terminal operators, answered that they actively finance local communities' initiatives. The organisation of workshops aimed at raising awareness on the social and environmental impacts of the respondents is a popular practice amongst port managing bodies (60\%), while a not very common practice for terminal operators (30\%). A similar conclusion can be drawn regarding port or company open days. In total, $55 \%$ of port managing bodies and $47 \%$ of terminal operators organize port open days. Port Centers (port visitor or information centers open to the general public) are still a young and new concept implemented by a number of larger ports around the world [32]. While this concept is gaining more interest, the actual number of implemented Port Centers remains low, particularly amongst the respondents. In total, three port managing bodies and three port terminals reported having a Port Center open to the public.

\subsubsection{Public Consultation}

A limited number of proposed public engagement mechanisms through closed-ended questions and generated from open-ended questions in the survey have been categorized as public consultation mechanisms. These mechanisms allow for an effective information stream between the survey respondents and their local communities. More particularly, the flow of information enabled through public consultation mechanisms originates from the local communities and is transferred to port managing bodies or terminal operators [51]. In this particular case, the initiative to reach out should come from the local communities themselves. Nevertheless, port managing bodies and terminal operators can enable such engagement practices by making public consultation mechanisms available to their local communities.

Results disclose that e-mail addresses, webforms, and phone numbers are the most frequently provided tools on the websites of the respondents, allowing local communities to interact with port managing bodies and terminal operators. These tools allow local communities to reach out, on their own initiative, to port managing bodies and terminal operators.

As port managing bodies and terminal operators generate impacts on different levels of society, sustaining healthy public relations is crucial. Keeping track of possible complaints by local community stakeholders is essential. Therefore, $85 \%$ of port managing bodies and $88 \%$ of terminal operators keep track of complaints made by external stakeholders (Table 2). 
Table 2. Tracking of complaints and feedback process in place.

\begin{tabular}{|c|c|c|c|c|c|c|c|}
\hline & & \multicolumn{2}{|c|}{ Port Managing Body } & \multicolumn{2}{|c|}{ Terminal Operator } & \multicolumn{2}{|c|}{ Total } \\
\hline & & $\mathbf{N}$ & $\mathbf{N} \%$ & $\mathbf{N}$ & $\mathrm{N} \%$ & $\mathbf{N}$ & $\mathrm{N} \%$ \\
\hline \multirow{2}{*}{$\begin{array}{l}\text { Do you register/keep } \\
\text { track of complaints? }\end{array}$} & Yes & 17 & $85 \%$ & 15 & $88 \%$ & 32 & $86 \%$ \\
\hline & No & 3 & $15 \%$ & 2 & $12 \%$ & 5 & $14 \%$ \\
\hline \multicolumn{2}{|l|}{ Total } & 20 & $100 \%$ & 17 & $100 \%$ & 37 & $100 \%$ \\
\hline \multirow{3}{*}{$\begin{array}{l}\text { Feedback process (only } \\
\text { if answer is YES to } \\
\text { previous question) }\end{array}$} & Yes & 13 & $65 \%$ & 12 & $71 \%$ & 25 & $68 \%$ \\
\hline & No & 4 & $20 \%$ & 3 & $18 \%$ & 7 & $19 \%$ \\
\hline & Not applicable & 3 & $15 \%$ & 2 & $12 \%$ & 5 & $14 \%$ \\
\hline \multicolumn{2}{|l|}{ Total } & 20 & $100 \%$ & 17 & $100 \%$ & 37 & $100 \%$ \\
\hline
\end{tabular}

In this regard, Darbra et al. [56] emphasize that ports' initiatives to gather data on their environmental impact and performance has been pushed through complaints from third parties. This finding discloses the importance of engaging in complaints tracking practices. Nevertheless, the process of providing formal feedback reaches lower relative frequencies amongst the respondents with, respectively, $65 \%$ for port managing bodies and $71 \%$ for terminal operators. Results show that not all respondents are actively engaged in tackling the different issues provided through local communities' complaints. However, at final, no major differences in public consultation mechanisms between port managing bodies and terminal operators are noted.

\subsubsection{Public Participation}

Public participation mechanisms enable two-way information streams brought in place by the port managing bodies and terminal operators. These mechanisms imply, to a certain extent, a higher level of information exchange and formal interaction between both port managing bodies or terminals operators and local communities [51].

Port managing bodies and terminal operators disclose a predominant tendency towards holding regular meetings with the community and stakeholders at large. Respectively, $60 \%$ of the port managing bodies and $59 \%$ of the terminal operators organize meetings with their external stakeholders regularly. However, the existence of a permanent local community committee and the presence of local communities' representative(s) on the Board of Directors is a relative infrequent practice. In both cases, $40 \%$ of the port managing bodies responded favorably to such practice, while terminal operators disclose lower relative frequencies with, respectively, $29 \%$ and $6 \%$. The presence of an independent ombudsman is exceptional. Only one terminal operator answered making use of an independent ombudsman (Table 3).

Regardless of the discussed public participation mechanisms, the act of engaging and consulting local communities and external stakeholders over the existence of a port cluster and more specifically over the course of a project (e.g., extension of a port terminal) is important [57]. Using the gathered information, adjustments to strategic decisions can be arranged in order to meet external stakeholders' expectations and desires. The incorporation of local communities and external stakeholder's opinions and feedback strongly depends on port cluster stakeholder's unique ability and willingness to do so. However, depending on the geographic location of port managing bodies and terminal operators, the act of including local communities in further discussion regarding a specific project or the daily activities can be required by law or permit. As a consequence, two closeended questions have been formulated regarding the extent to which local communities are consulted before and after the approval to proceed with a project. A majority of port managing bodies $(60 \%)$ and terminal operators $(59 \%)$ consult local communities depending on the type(s) of possible significant impact of their activities and projects. Accordingly, $55 \%$ of port managing bodies and $59 \%$ of terminal operators communicate with local communities beyond the approval phase of a project depending on the nature of the project 
or its potential implications. At final, only a minority of respondents engages in such practices due to legal requirements or a permit procedure.

Table 3. Public participation mechanisms.

\begin{tabular}{|c|c|c|c|c|c|c|c|}
\hline & & \multicolumn{2}{|c|}{ Port Managing Body } & \multicolumn{2}{|c|}{ Terminal Operator } & \multicolumn{2}{|c|}{ Total } \\
\hline & & $\mathbf{N}$ & $\mathbf{N} \%$ & $\mathbf{N}$ & $\mathbf{N} \%$ & $\mathbf{N}$ & $\mathbf{N} \%$ \\
\hline \multirow{3}{*}{$\begin{array}{l}\text { Regular meetings with the port's or } \\
\text { company's community and stakeholders (the } \\
\text { subject matter and questions coming from } \\
\text { the community directly at least twice a year) }\end{array}$} & Yes & 12 & $60 \%$ & 10 & $59 \%$ & 22 & $59 \%$ \\
\hline & No & 4 & $20 \%$ & 5 & $29 \%$ & 9 & $24 \%$ \\
\hline & No answer & 4 & $20 \%$ & 2 & $12 \%$ & 6 & $16 \%$ \\
\hline Total & & 20 & $100 \%$ & 17 & $100 \%$ & 37 & $100 \%$ \\
\hline \multirow{3}{*}{$\begin{array}{l}\text { The presence of an independent ombudsman } \\
\text { (an independent officer representing the } \\
\text { interest of the public by investigating and } \\
\text { addressing complaints) }\end{array}$} & Yes & 0 & $0 \%$ & 1 & $6 \%$ & 1 & $3 \%$ \\
\hline & No & 16 & $80 \%$ & 13 & $76 \%$ & 29 & $78 \%$ \\
\hline & No answer & 4 & $20 \%$ & 3 & $18 \%$ & 7 & $19 \%$ \\
\hline Total & & 20 & $100 \%$ & 17 & $100 \%$ & 37 & $100 \%$ \\
\hline \multirow{3}{*}{$\begin{array}{l}\text { The existence of a permanent local } \\
\text { community committee }\end{array}$} & Yes & 8 & $40 \%$ & 5 & $29 \%$ & 13 & $35 \%$ \\
\hline & No & 8 & $40 \%$ & 9 & $53 \%$ & 17 & $46 \%$ \\
\hline & No answer & 4 & $20 \%$ & 3 & $18 \%$ & 7 & $19 \%$ \\
\hline Total & & 20 & $100 \%$ & 17 & $100 \%$ & 37 & $100 \%$ \\
\hline \multirow{3}{*}{$\begin{array}{c}\text { Representative(s) of local communities on } \\
\text { the Board of Directors }\end{array}$} & Yes & 8 & $40 \%$ & 1 & $6 \%$ & 9 & $24 \%$ \\
\hline & No & 8 & $40 \%$ & 13 & $76 \%$ & 21 & $57 \%$ \\
\hline & No answer & 4 & $20 \%$ & 3 & $18 \%$ & 7 & $19 \%$ \\
\hline Total & & 20 & $100 \%$ & 17 & $100 \%$ & 37 & $100 \%$ \\
\hline
\end{tabular}

\subsection{Local Communities' Perceptions}

Next to having a better understanding of the different public engagement mechanisms applied by port managing bodies and terminal operators used to foster a relationship with external stakeholders and local communities, respondents were asked about their own perception regarding the impacts of their activities on external stakeholders and local communities. Furthermore, the survey tries to assess, through closed-ended questions and open-ended questions, whether the respondents track and quantify their impact on society through local communities' perceptions, or in other words, their social license to operate.

Results disclose that the respondents are positive in terms of self-reflection. In total, $70 \%$ of port managing bodies believe that their position within the local community has improved or remained stable over the past five years. This figure is higher for terminal operators $(76 \%)$ (Table 4$)$. No single participant believes that the position and the perception of local communities towards its activities has deteriorated.

Accordingly, the respondents were asked how they perceive their own current level of acceptance by their local communities. For this purpose, a 7-level Likert-scale has been used (from 1 (=not generally accepted) to 7 (=very accepted)). The results are disclosed in Figure 2. 
Table 4. Evolution in local communities' perceptions towards respondents' activities.

\begin{tabular}{|c|c|c|c|c|c|c|c|}
\hline & & \multicolumn{2}{|c|}{ Port Managing Body } & \multicolumn{2}{|c|}{ Terminal Operator } & \multicolumn{2}{|c|}{ Total } \\
\hline & & $\mathbf{N}$ & $\mathrm{N} \%$ & $\mathbf{N}$ & $\mathrm{N} \%$ & $\mathbf{N}$ & $\mathrm{N} \%$ \\
\hline \multirow{6}{*}{$\begin{array}{l}\text { Over the past five years, } \\
\text { how have the } \\
\text { local communities' } \\
\text { perceptions towards } \\
\text { your activities evolved? }\end{array}$} & $\begin{array}{l}\text { They have } \\
\text { improved }\end{array}$ & 7 & $35 \%$ & 8 & $47 \%$ & 15 & $41 \%$ \\
\hline & $\begin{array}{c}\text { They have } \\
\text { remained stable }\end{array}$ & 7 & $35 \%$ & 5 & $29 \%$ & 12 & $32 \%$ \\
\hline & $\begin{array}{c}\text { They have } \\
\text { deteriorated }\end{array}$ & 0 & $0 \%$ & 0 & $0 \%$ & 0 & $0 \%$ \\
\hline & $\begin{array}{l}\text { I don't know/ } \\
\text { It is unclear }\end{array}$ & 2 & $10 \%$ & 2 & $12 \%$ & 4 & $11 \%$ \\
\hline & $\begin{array}{l}\text { Other (please spec- } \\
\text { ify)/Comments }\end{array}$ & 2 & $10 \%$ & 1 & $6 \%$ & 3 & $8 \%$ \\
\hline & No answer & 2 & $10 \%$ & 1 & $6 \%$ & 3 & $8 \%$ \\
\hline \multicolumn{2}{|l|}{ Total } & 20 & $100 \%$ & 17 & $100 \%$ & 37 & $100 \%$ \\
\hline
\end{tabular}

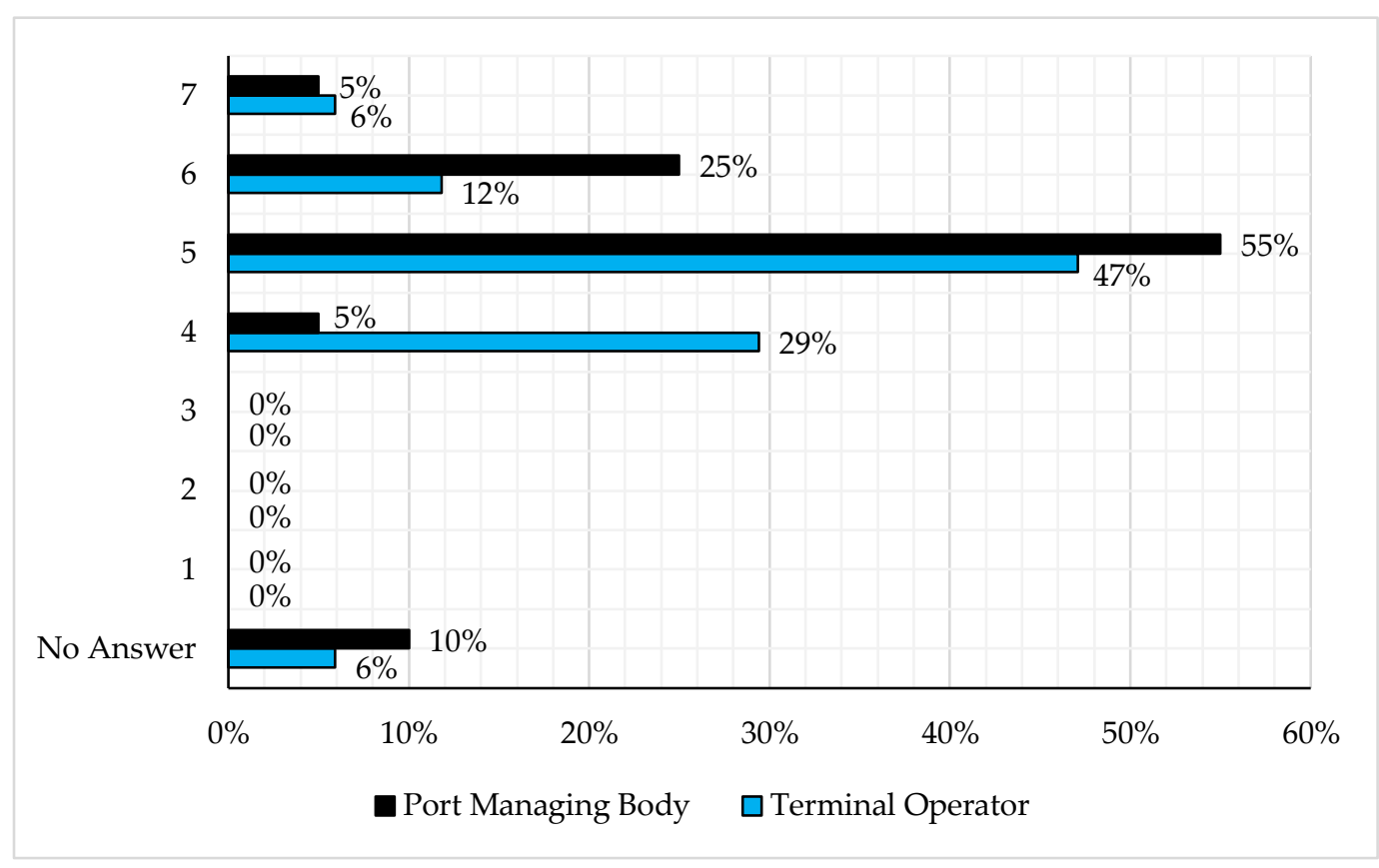

Figure 2. Respondents' perception of their current level of acceptance by the local communities (relative frequencies for indicated scores from 1 to 7 ).

Regarding port managing bodies, 55\% estimate their position within the local community as accepted (level 5). Out of the terminal operators, $47 \%$ perceive themselves as accepted by their local communities. Nevertheless, $29 \%$ of terminal operators claim that their current level of local communities' acceptance is neutral (level 4). Similarly, respondents were questioned whether they measure the perceptions of their local communities, and whether they would engage in such measurement exercises if they had not actively done it in the past (Table 5). 
Table 5. Perception measurement by the respondents.

\begin{tabular}{|c|c|c|c|c|c|c|c|}
\hline & & \multicolumn{2}{|c|}{ Port Managing Body } & \multicolumn{2}{|c|}{ Terminal Operator } & \multicolumn{2}{|c|}{ Total } \\
\hline & & $\mathbf{N}$ & $\mathbf{N} \%$ & $\mathbf{N}$ & $\mathbf{N} \%$ & $\mathbf{N}$ & $\mathrm{N} \%$ \\
\hline \multirow{3}{*}{$\begin{array}{l}\text { Measurement of } \\
\text { the communities' } \\
\text { perceptions towards } \\
\text { business/operations }\end{array}$} & Yes & 9 & $45 \%$ & 3 & $18 \%$ & 12 & $32 \%$ \\
\hline & No & 9 & $45 \%$ & 13 & $76 \%$ & 22 & $59 \%$ \\
\hline & No answer & 2 & $10 \%$ & 1 & $6 \%$ & 3 & $8 \%$ \\
\hline \multicolumn{2}{|l|}{ Total } & 20 & $100 \%$ & 17 & $100 \%$ & 37 & $100 \%$ \\
\hline \multirow{4}{*}{$\begin{array}{l}\text { Would you consider } \\
\text { measuring the } \\
\text { communities' perceptions } \\
\text { towards your } \\
\text { business/operations? }\end{array}$} & Yes & 8 & $40 \%$ & 6 & $35 \%$ & 14 & $38 \%$ \\
\hline & No & 2 & $10 \%$ & 5 & $29 \%$ & 7 & $19 \%$ \\
\hline & Not applicable & 8 & $40 \%$ & 3 & $18 \%$ & 11 & $30 \%$ \\
\hline & No answer & 2 & $10 \%$ & 3 & $18 \%$ & 5 & $14 \%$ \\
\hline \multicolumn{2}{|l|}{ Total } & 20 & $100 \%$ & 17 & $100 \%$ & 37 & $100 \%$ \\
\hline
\end{tabular}

Perception assessment exercises are more applied by port managing bodies (45\%) compared to terminal operators $(18 \%)$. In total, $32 \%$ of the respondents claim to engage in perception measurement practices. The respondents provided different reasons and incentives to engage in perception measurement: benchmarking against other waterfront businesses, useful information for business and communication planning, understanding the community needs, successful operations and growth, and being a good corporate citizen. As a consequence, focus groups, telephone surveys, community workshops, the social media, polling, and liaison committees are prominent methods applied by the respondents in order to assess their social license to operate. However, $59 \%$ of the respondents do not, by any means, assess the perception of their local communities. Respectively, $76 \%$ of terminal operators and $45 \%$ of port managing bodies do not engage in such activities. The respondents reported to lack knowledge and resources concerning existing measurement methods and performance measures. Finally, different types of metrics, forming potential key social performance indicators, were proposed to the respondents. Respondents were questioned on the relevancy of each metric to measure or assess local communities' perceptions (Figure 3).

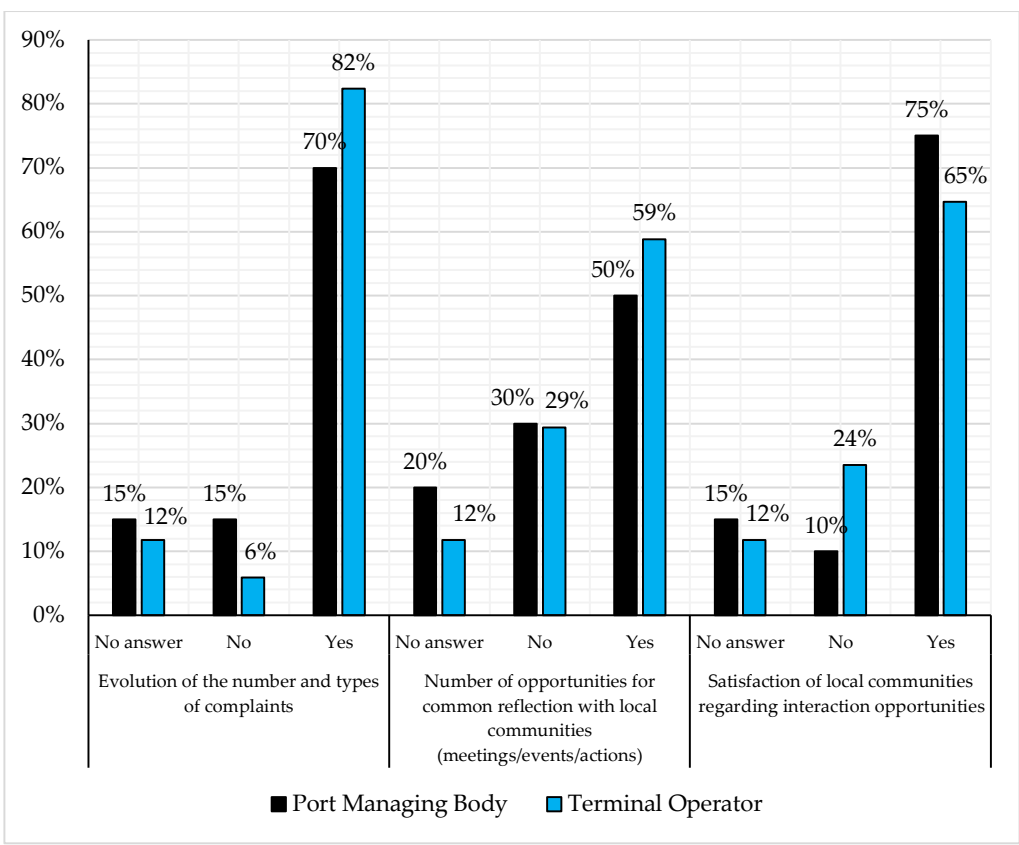

Figure 3. Metrics for perception measurement (relative frequencies of provided answers per metric). 
The relative frequency of "no answer" per proposed metric is high (from 11\% to $50 \%$ in some cases). Metrics for which more than $80 \%$ of answers have been provided are considered: the evolution of the number and types of complaints, the number of opportunities for common reflection with local communities (meetings/events/actions), and the satisfaction of local communities regarding interaction opportunities. The evolution of the number and types of complaints is assumed and believed to be a strong metric amongst the respondents. From $70 \%$ of port managing bodies to $82 \%$ of terminal operators believe that keeping track of complaints is a reflection of society's and local community's level of acceptance. Furthermore, port managing bodies report a high share (75\%) on the satisfaction of local communities regarding interaction opportunities. Terminal operators disclose a $65 \%$ share with regards to the same metric. Regarding the number of opportunities for common reflection with local communities (meetings/events/actions), respondents provided a smaller share of positive answers compared to the previous metric. Respectively $50 \%$ of port managing bodies and 59\% of terminal operators assume this metric as relevant.

\subsection{Value-Added and Barriers of Engaging with Local Communities}

The conducted in-depth interviews provided valuable information concerning the value added of engaging with local communities. Furthermore, the interviewees provided insights regarding the different barriers having an impact on a port managing body's ability to connect and build a relationship with local communities.

Based on our interviews, the value added for port managing bodies can be translated into three categories: Economical, environmental, and social. In economical terms, reaching out to local communities and external stakeholders provides a better image for the participant's organisation, potentially boosting its activities and revenues, hence generating wealth for the broader society.

"To the extent that regulation is always a cost, the more smoothly we can get through a regulatory process as a result of a good approach to stakeholder engagement, the better. That regulatory process in the end reduces cost, and we think that it is a value to have the port take that on."

(Port managing body interview participant 5)

Regarding the environmental value added, the fact that local communities are heard and considered enables port authorities to adjust their strategy and take into consideration actions to dampen their impact on the environment.

"It enables an advanced read on issues that are important to the community. There are issues that are emerging. We want to know what neighbors are interested in and concerned about (like traffic or air quality). We hope to get an early read-on to that kind of things from individuals before it becomes a big issue."

(Port managing body interview participant 5)

Finally, the social aspect is more general. Reaching out to local communities gives the port managing body a chance to hear the local communities, and to adjust as a consequence. It helps local communities to be educated about a certain topic. As a consequence, it enables ports to create trust amongst their communities and be close to local communities' concerns.

"Education and supporting education, exposing people to the maritime industry."

(Port managing body interview participant 6)

"By doing so, it gives an indication of people's perception concerning our activities."

(Port managing body interview participant 1 )

From our interviews, it can be concluded that the barriers to reach out to local communities fall into two broad and distinct categories: internal and external barriers. Internal barriers flow out of the port managing body's organizational characteristics. Internal resources in terms of financials and human capital are amongst the most frequent provided reasons for not being able to perform outreach activities and engage in citizen participation 
practices. These findings are in line with earlier discussed results regarding the practice of measuring the social license to operate. Furthermore, some respondents emphasize that disbelief regarding public engagement mechanisms could exist within the organization. Internally, some employees do not reckon the utility to reach out and build a relationship, and potentially even oppose such decisions to do so.

"I really am, in essence, able to give money to a couple of economic development and maritime stakeholders. And so, the neighborhood associations, the other community stakeholders, the ones that at the end of the day are probably the folks that might have a least favorable perception of our organization are not the people I can give sponsorship dollars to."

(Port managing body interview participant 4)

"I always have to tell my board that there is always so much we can do because we don't have more money and we don't have more people."

(Port managing body interview participant 8)

"Internally there is a bit of convincing to be done around the merits of public engagement. If we go down this path does it mean that we are feeding our decision-making according to our stakeholders? There is a lot of internal resistance to that."

(Port managing body interview participant 5)

Finally, external barriers are barriers arising from the local communities. Based on the conducted interviews we conclude that (mis)trust is a significant issue for port managing bodies. In the case that mistrust is present, local communities are not willing to collaborate and cooperate with the port managing body. Mistrust is, based on our interviews, the result of historical facts and negative impacts generated by the port.

"There is a lot of mistrust between the community and the port [... ]. We are not in a place where there is a lot of trust, we tend to go into communities and hear about things that might have happened even generations ago. As the port has come back online and started reactivating and building volumes there is a resentment."

(Port managing body interview participant 4)

\section{Discussion}

The power and influence of local communities on port activities has been documented and researched in the past. This research paper aimed to explore the public engagement practices and mechanisms applied by the North American port industry to foster a social license to operate. To a further extent, the way and means by which North American port managing bodies and terminal operators assess their impacts on society, through local communities' perception, have been examined. Our research was enabled via the dissemination of a voluntary survey amongst port managing bodies and terminal operators in North America and subsequent conducted in-depth interviews with North American port managing bodies. Based on the results from the disseminated survey and performed interviews, additional insights are gathered in light of this research.

Our findings indicate that the definition of local communities is controversial to a certain extent. According to Notteboom and Winkelmans [7], community stakeholders are guided by local rationality and opportunistic behavior, looking for their own individual well-being above the well-being of a greater community. Such community stakeholders are civil society organizations, the general public, the press and other non-market players. Voyer and van Leeuwen [28] define two types of local community stakeholders: communities of place and communities of practice. The former is defined as geographically discrete communities in the surroundings of an industry such as neighbors and indigenous people. The latter corresponds to stakeholders having shared ideas and interests with a certain industry, being particularly vocal in case of industrial developments. Examples are non- 
governmental organisations (NGOs) and user groups. As a consequence of these different existing definitions, the participants to our survey were asked to identify stakeholders that could be considered part of their local communities. Furthermore, the participants were invited to share their level of consideration for every local community stakeholder they previously identified. As a result, communities being geographically close to a port's or terminal's surroundings are the most frequently identified local community stakeholder and similarly, the highest considered local community stakeholder amongst the respondents. This definition and identification of local community stakeholders is line with the marine environment and port management literature $[7,28]$. Nevertheless, results further disclose that, in comparison to existing definitions in the literature, market players (clients, suppliers, etc.) are identified and considered by the respondents as local community stakeholder as well. This actually implies a broader definition of local communities compared to the existing marine environment and port management literature $[7,28]$. However, no further major differences in local community's delineation have been found between North American port managing bodies and terminal operators and the literature on the topic. The retrieved and gathered results show that the respondents tend to broadly define their local community stakeholders, being the local communities with whom the respondents potentially publicly engage. The pure definition of local community stakeholders is dependent on every actor's own situation. This has a number of managerial implications for each port managing body and terminal operator. In order to be able to effectively assess their position against local communities, it is of crucial importance to consistently define the scope and the different actors of this stakeholder group. The pure nature and definition of local community stakeholders is not static but dynamic, evolving over time. A frequent assessment and redefinition of one's local communities is thus vital.

The use and application of public engagement mechanisms targeted towards local communities in the North American port industry is diverse and extensive, as previous results disclose for seaports [23]. Above all, social media channels as a communication tool are popular amongst the survey respondents. Furthermore, the results emphasize that the disclosure of a strategic plan and sustainability report by North American port managing bodies is a frequent practice. On the other hand, terminal operators are less engaged in the active disclosure of their environmental and societal impacts, and to a lesser extent of their strategic vision. Our results are in line with previous research performed regarding sustainability reporting by port managing bodies. Dooms [8] emphasizes the increased application of sustainability reporting in the port industry, as a way of assessing the societal and environmental impacts of port activities on stakeholders. Recent research performed by Geerts and Dooms [58] also confirms that reporting on sustainable practices and triple-bottom line performance in the port industry is gaining popularity in recent years. However, the reasons for differences between port managing bodies and terminal operators on this practice are further to be researched. Possible reasons could lie in the organizations' size and scale, and the geographical position of terminal operators within the vicinity of a port cluster itself, physically distancing it from local communities to a certain extent.

Explorative questions relating to self-perception and perception measurement practices proved to provide interesting results for discussion. In terms of self-perception the respondents are rather positive than negative. No single participant believes that its position and the acceptance of local communities towards its activities has deteriorated over the last years. Nevertheless, the self-perception can differ depending on the external stakeholder considered. One particular comment of a port managing body confirms this statement:

"It is very complicated, it is an evolving relationship as there are many different groups and audiences in the local community, some have improved and some have deteriorated, you can't lump all of the different facets and stakeholders into one group, it is much too nuanced." 
Similarly, when the respondents are asked to reflect on their present level of acceptance by their local communities the figures present a tendency towards high levels of consideration and acceptance. However, these figures do not reflect the actual position of port managing bodies and terminal operators vis-à-vis local communities. Local communities perceptions can only truly and effectively be assessed through specific mechanisms designed for such exercise and by local communities themselves. As a consequence, responses have been gathered relating to this subject. Results disclose that the perceptions of local communities are measured and captured by a minority of port managing bodies and terminal operators. These findings have a managerial implication. More specifically, through aggregation of the results, we find that a majority of respondents do not actively engage in the measurement of local communities' perceptions, however, considers being accepted by them. The respondents even assume that the acceptance of local communities towards their activities have improved. Moreover, the strategic importance of such measurement exercise is stressed by the respondents throughout the survey (e.g., useful for benchmarking and planning), meaning that the effective and accurate application of a social license to operate measurement practice is therefore desired and essential. The aggregation of these findings forms a paradox as a consequence. Furthermore, the methods used and mentioned by the respondents to capture the perception of their local communities (focus groups, telephone surveys, etc.) imply a high level of subjectivism, and do not allow to quantify and to capture the essence of the social license to operate. No formal and adequate procedure to quantify the social license to operate is performed by the respondents. The reason for this is the lack of available financial and human capital means to port managing bodies and terminal operators. Furthermore, the lack of knowledge regarding the subject is also a reason for not engaging in such measurement exercise. The respondents are not informed about existing valid social license to operate measurement methods in the literature (technical ones-see Thomson and Boutilier [44], and vulgarized ones—see Black [59]). However, one could argue that these methods are not tailored to the port industry and its unique setting.

These findings are in line with the performed interviews with port managing bodies in this research. While the lack of internal resources (financial and human capital means) is the most frequently provided reason, the diverging beliefs and opinions within the port managing body's structure regarding the subject of the social license to operate also form a barrier. This highlights the need to better define the concept and educate organizational members on the topic. From an external perspective, the most noted issue is mistrust resulting from historical facts and negative impacts caused by the port managing bodies. It has further been noted that the value-added (economical, environmental, and social) for engaging with local communities is in line with the findings of Dooms [8] in terms of sustainability performance of port managing bodies and the port industry as a whole.

Finally, the evolution of the number and types of complaints, the number of opportunities for common reflection with local communities and the satisfaction of local communities regarding interaction opportunities are regarded by the respondents as relevant metrics to assess local communities' perceptions towards their activities. These findings are in line with previous findings by Deforche et al. [35]. The question here is whether the aforementioned metrics fundamentally capture the essence of local communities' perceptions and a social license to operate. This thought is expressed through the following statement of one the survey participants:

“A company can't be judged by how much of something it does (e.g., community investment or communication), but only by how those actions are perceived by the target (i.e., the community)."

(Terminal operator survey participant)

\section{Conclusions}

The findings of our research, and its limitations, provide some insightful implications for future research and decision-makers. First, while an extensive sample of participants has been selected, with a satisfactory response level for a study in the port industry, only a 
limited number of responses have been collected. Increasing the number of participants and subsequent responses will provide a stronger basis for generalization of the results. Second, the survey has been disseminated among North American port managing bodies and port authorities. In consequence, this research could be geographically extended to other regions, allowing for a better representativeness of the situation in the port industry and further benchmarking between different regions. Furthermore, the theoretical models of Rowe and Frewer [51] and Moffat and Zhang [54] used to design the survey in this research respectively find their roots in other fields than the port industry and port management literature. As a consequence, it would be valuable to determine a typology of public engagement mechanisms [51] and a model of critical elements influencing the creation of a social license to operate [54], unique to the port industry. Finally, our findings disclose the necessity to conduct further research regarding the quantification of the social license to operate. Few attempts have been made in order to measure and to quantify the perception of local communities regarding the activities of port clusters. The empirical applications within the mining industry form a good basis on which further work and generalization towards the port industry can be made. Today, close collaboration between port managing bodies and their respective local communities, and the development of in-depth knowledge on the topic is essential. In order to assess a port's sustainability score, and more particularly its social sustainability score, local communities' perceptions need to be evaluated and tracked in order to create an additional layer improving stakeholder management in ports. Therefore, it is important to raise awareness regarding the importance of the social license to operate in ports, its quantification and the application of sustainability strategies that confer an actual social license to operate.

Author Contributions: Conceptualization, M.D.; methodology, B.M. and M.D.; validation, M.D.; formal analysis, B.M.; investigation, B.M.; writing—original draft preparation, B.M.; writing—review and editing, M.D.; visualization, B.M.; supervision, M.D.; project administration, B.M. \& M.D.; funding acquisition, M.D. All authors have read and agreed to the published version of the manuscript.

Funding: This research was partly funded by the Social Sciences and Humanities Research Council (SSHRC) of the Government of Canada, project title, "Green Shipping: Governance \& Innovation for a Sustainable Maritime Supply Chain." The APC was funded by Social Sciences and Humanities Research Council of the Government of Canada: project title, "Green Shipping: Governance \& Innovation for a Sustainable Maritime Supply Chain."

Institutional Review Board Statement: Not applicable.

Informed Consent Statement: Not applicable.

Acknowledgments: The research team wishes to thank Green Marine for the valuable collaboration to and support for this research. We particularly thank Green Marine's executive director, for his valuable support, input, and feedback over the research process.

Conflicts of Interest: The authors declare no conflict of interest. 


\section{Appendix A}

Table A1. Academic literature on the social license to operate in the marine environment literature and the port management literature.

\begin{tabular}{|c|c|c|c|c|c|}
\hline Field & Author (Year) & Research & Methods & Results & Recommendations \\
\hline \multirow{4}{*}{$\begin{array}{c}\text { Marine } \\
\text { environment literature }\end{array}$} & Cullen-Knox et al. [39] & $\begin{array}{l}\text { A study describing the } \\
\text { mechanisms by which the } \\
\text { social license to operate is } \\
\text { gained or lost and the } \\
\text { influence on public policy } \\
\text { and management } \\
\text { decisions-making processes }\end{array}$ & $\begin{array}{l}\text { Expert interviews, text } \\
\text { analysis and case study } \\
\text { interviews with } \\
\text { key stakeholders }\end{array}$ & $\begin{array}{l}\text { The social license to operate is } \\
\text { dynamic and has importance in } \\
\text { progressive discourse } \\
\text { regarding the use of resources. }\end{array}$ & $\begin{array}{l}\text { Decision-making has to be } \\
\text { flexible since the social license to } \\
\text { operate changes } \\
\text { how government } \\
\text { responds to societal demands. }\end{array}$ \\
\hline & Kelly et al. [40] & $\begin{array}{l}\text { A review of the use of the } \\
\text { term 'social license to operate' } \\
\text { in the marine } \\
\text { environment literature }\end{array}$ & $\begin{array}{l}\text { Literature searches using } \\
\text { three databases }\end{array}$ & $\begin{array}{l}\text { The concept of social license to } \\
\text { operate and use of word is } \\
\text { emerging in the marine sector. }\end{array}$ & $\begin{array}{l}\text { The social license to operate may } \\
\text { have potential to guarantee } \\
\text { engagement in case marine } \\
\text { management is designed in a } \\
\text { way that social uses and interests } \\
\text { can be appropriately } \\
\text { accommodated. }\end{array}$ \\
\hline & Voyer and van Leeuwen [28] & $\begin{array}{l}\text { An assessment of the social } \\
\text { license to operate of the Blue } \\
\text { Economy, an ocean based } \\
\text { economic growth model }\end{array}$ & $\begin{array}{l}\text { Interviews, a survey and a } \\
\text { workshop with the ocean } \\
\text { business community }\end{array}$ & $\begin{array}{l}\text { The social license to operate is } \\
\text { operationalized using technical } \\
\text { strategies and one-way } \\
\text { engagement strategies. }\end{array}$ & $\begin{array}{l}\text { Active and critical engagement } \\
\text { related to shared responsibilities } \\
\text { of public and private actors in the } \\
\text { Blue Economy is required to } \\
\text { build and maintain a social } \\
\text { license to operate. Furthermore, } \\
\text { appropriate methods should be } \\
\text { found to understand, manage } \\
\text { and monitor a social } \\
\text { license to operate. }\end{array}$ \\
\hline & Kelly et al. [41] & $\begin{array}{l}\text { An exploration of the social } \\
\text { license to operate's practical } \\
\text { application in the case of } \\
\text { marine protected areas. In } \\
\text { this regard, a perception } \\
\text { study of marine stakeholders } \\
\text { in Tasmania } \\
\text { has been performed. }\end{array}$ & $\begin{array}{l}\text { Q-method and } \\
\text { semi-structured interviews of } \\
\text { marine stakeholders } \\
\text { in Tasmania }\end{array}$ & $\begin{array}{l}\text { The social license to operate for } \\
\text { marine protected areas is } \\
\text { highly nuanced. } \\
\text { Commonalities and shared } \\
\text { perspectives have been } \\
\text { identified that can be useful for } \\
\text { further marine } \\
\text { management development. }\end{array}$ & $\begin{array}{l}\text { The social license to operate is a } \\
\text { promising future tool for marine } \\
\text { management improvement. The } \\
\text { application of Q-method in the } \\
\text { context of the social license to } \\
\text { operate might be interesting for } \\
\text { future research. }\end{array}$ \\
\hline
\end{tabular}


Table A1. Cont.

\begin{tabular}{|c|c|c|c|c|c|}
\hline Field & Author (Year) & Research & Methods & Results & Recommendations \\
\hline \multirow{3}{*}{$\begin{array}{c}\text { Port } \\
\text { management literature }\end{array}$} & Ircha [42] & $\begin{array}{l}\text { A review of public } \\
\text { engagement initiatives } \\
\text { carried out by Canadian and } \\
\text { international port clusters } \\
\text { aimed at obtaining and } \\
\text { maintaining a social } \\
\text { license to operate }\end{array}$ & $\begin{array}{l}\text { Web-search of selected } \\
\text { Canadian and } \\
\text { international ports }\end{array}$ & $\begin{array}{l}\text { The presence of an active } \\
\text { interaction with local } \\
\text { communities of surveyed } \\
\text { Canadian and } \\
\text { international ports. }\end{array}$ & $\begin{array}{l}\text { It is essential for ports to balance } \\
\text { their broad commercial functions } \\
\text { with a social license to operate. }\end{array}$ \\
\hline & Deforche et al. [33] & $\begin{array}{l}\text { A perception-based research } \\
\text { of local communities of the } \\
\text { Port of Antwerp }\end{array}$ & $\begin{array}{l}\text { Interviews and focus groups } \\
\text { with local community } \\
\text { stakeholders }\end{array}$ & $\begin{array}{l}\text { Local communities' experiences } \\
\text { and perceptions need to be } \\
\text { quantified and disclosed. }\end{array}$ & $\begin{array}{l}\text { The disclosure of the assessment } \\
\text { and quantification of the social } \\
\text { license to operate under the form } \\
\text { of an indicator would contribute } \\
\text { to an even stronger } \\
\text { social license to operate }\end{array}$ \\
\hline & Dooms [8] & $\begin{array}{l}\text { An exploratory study linking } \\
\text { and integrating triple bottom } \\
\text { line performance with the } \\
\text { social license to operate }\end{array}$ & $\begin{array}{l}\text { Grounded } \\
\text { theory/exploratory } \\
\text { qualitative research }\end{array}$ & $\begin{array}{l}\text { A conceptual framework and } \\
\text { matrix assessing triple bottom } \\
\text { line performance against the } \\
\text { social license to operate. }\end{array}$ & $\begin{array}{l}\text { The proposed framework is } \\
\text { suitable in case port managing } \\
\text { bodies have a strong autonomy } \\
\text { and local ownership. } \\
\text { Furthermore, the measurement } \\
\text { of the social license to operate } \\
\text { could improve triple bottom line } \\
\text { reporting. Nevertheless, } \\
\text { attention is needed regarding the } \\
\text { subjectivism of a social license to } \\
\text { operate indicator since additional } \\
\text { research is required to develop a } \\
\text { perception-based indicator. }\end{array}$ \\
\hline
\end{tabular}




\section{Appendix B}

Table A2. Categorisation of questions based on public engagement types.

\begin{tabular}{|c|c|c|}
\hline Question & Close-Ended & Public Engagement Type \\
\hline $\begin{array}{l}\text { Does your port or company website have a section } \\
\text { dedicated to the local communities? }\end{array}$ & Close-ended & Public communication \\
\hline $\begin{array}{c}\text { Which type of information is available on your website to allow the local } \\
\text { community to interact? Please specify. }\end{array}$ & Open-ended & Public consultation \\
\hline \multicolumn{3}{|l|}{ Which of the following communication tools do you have available? } \\
\hline $\begin{array}{l}\text { - A publicly available sustainability report/environmental } \\
\text { report/corporate social responsibility report }\end{array}$ & Close-ended & Public communication \\
\hline - A publicly available strategic plan & Close-ended & Public communication \\
\hline - A newsletter oriented towards the local communities & Close-ended & Public communication \\
\hline $\begin{array}{c}\text { - A dedicated website page about sustainability, corporate social } \\
\text { responsibility and/or local communities }\end{array}$ & Close-ended & Public communication \\
\hline - A TV/YouTube channel & Close-ended & Public communication \\
\hline - Any social media account (Facebook, Twitter, Instagram, other); & Close-ended & Public communication \\
\hline - Other & Open-ended & Depending on the generated answer. To be determined. \\
\hline - If so, do you have a formal feedback/follow-up process in place? & Close-ended & Public consultation \\
\hline \multicolumn{3}{|l|}{ What types of local community engagement techniques do you apply? } \\
\hline $\begin{array}{c}\text { - Regular meetings with the port's or company's community and } \\
\text { stakeholders (the subject matter and questions coming from the } \\
\text { community directly at least twice a year) }\end{array}$ & Close-ended & Public participation \\
\hline $\begin{array}{l}\text { - The presence of an independent ombudsman } \\
\text { (an independent officer representing the interest of the public by } \\
\text { investigating and addressing complaints) }\end{array}$ & Close-ended & Public participation \\
\hline - The existence of a permanent local community committee & Close-ended & Public participation \\
\hline - Representative(s) of local communities on the Board of Directors & Close-ended & Public participation \\
\hline - Financial support of local community initiatives & Close-ended & Public communication \\
\hline
\end{tabular}


Table A2. Cont.

\begin{tabular}{|c|c|c|}
\hline Question & Close-Ended & Public Engagement Type \\
\hline $\begin{array}{c}\text { - The organisation of workshops regarding the port's or company's } \\
\text { operations and related social/environmental impacts }\end{array}$ & Close-ended & Public communication \\
\hline - Port or company open days & Close-ended & Public communication \\
\hline - A port or company visitor/information centre open to the general public & Close-ended & Public communication \\
\hline - Other & Open-ended & Depending on the generated answer. To be determined. \\
\hline $\begin{array}{l}\text { Do you organize direct local community consultation(s) before any } \\
\text { decision or approval to submit or proceed with a project involving } \\
\text { strategic decisions with possible significant impacts on a community? }\end{array}$ & Close-ended & Public participation \\
\hline $\begin{array}{l}\text { Do you maintain the communication established with your local } \\
\text { communities beyond the approval phase of a project } \\
\text { (i.e., throughout the project's duration and/or subsequently)? }\end{array}$ & Close-ended & Public participation \\
\hline
\end{tabular}




\section{References}

1. Hoyle, B.S. The Port—City Interface: Trends, Problems and Examples. Geoforum 1989, 20, 429-435. [CrossRef]

2. Ducruet, C.; Lee, S.-W. Frontline Soldiers of Globalisation: Port-City Evolution and Regional Competition. GeoJournal 2006, 67, 107-122. [CrossRef]

3. Adams, M.; Quinonez, P.; Pallis, A.; Wakeman, T. Environmental Issues in Port Competitiveness-Working Paper No. 7. 2009. Available online: https:/ / trid.trb.org/view / 916072 (accessed on 3 April 2020).

4. Haezendonck, E.; Dooms, M.; Verbeke, A. A New Governance Perspective on Port-Hinterland Relationships: The Port Hinterland Impact (PHI) Matrix. Marit. Econ. Logist. 2014, 16, 229-249. [CrossRef]

5. Goss, R.O. Economic Policies and Seaports: Are Port Authorities Necessary? Marit. Policy Manag. 1990, 17, 257-271. [CrossRef]

6. Moglia, F.; Sanguineri, M. Port Planning: The Need for a New Approach? Marit. Econ. Logist. 2003, 5, 413-425. [CrossRef]

7. Notteboom, T.E.; Winkelmans, W. Stakeholder Relations Management in Ports: Dealing with the Interplay of Forces among Stakeholders in a Changing Competitive Environment. In Proceedings of the International Association of Maritime Economists (IAME) 2002 Conference, Panama City, Panama, 10-13 June 2020.

8. Dooms, M. Integrating "triple $\mathrm{P}^{\prime}$ bottom line performance and the license to operate for ports: Towards new partnership between port cluster stakeholders. In Port-city Governance; Alix, Y., Delsalle, B., Comtois, C., Eds.; EMS: Caen, France, 2015 ; pp. 55-75.

9. Dooms, M.; Verbeke, A.; Haezendonck, E. Stakeholder Management and Path Dependence in Large-Scale Transport Infrastructure Development: The Port of Antwerp Case (1960-2010). J. Transp. Geogr. 2013, 27, 14-25. [CrossRef]

10. Notteboom, T.; Parola, F.; Satta, G.; Penco, L. Disclosure as a Tool in Stakeholder Relations Management: A Longitudinal Study on the Port of Rotterdam. Int. J. Logist. Res. Appl. 2015, 18, 228-250. [CrossRef]

11. Dooms, M. Crafting the Integrative Value Proposition for Large Scale Transport Infrastructure Hubs: A Stakeholder Management Approach. Ph.D. Dissertation, Vrije Universiteit Brussel, Brussels, Belgium, 2010.

12. Henriques, I.; Sadorsky, P. The Determinants of an Environmentally Responsive Firm: An Empirical Approach. J. Environ. Econ. Manag. 1996, 30, 381-395. [CrossRef]

13. Florida, R.; Davison, D. Gaining from Green Management: Environmental Management Systems inside and Outside the Factory. Calif. Manage. Rev. 2001, 43, 64-84. [CrossRef]

14. Delmas, M.; Toffel, M.W. Stakeholders and Environmental Management Practices: An Institutional Framework. Bus. Strat Environ. 2004, 13, 209-222. [CrossRef]

15. Sharma, S.; Henriques, I. Stakeholder Influences on Sustainability Practices in the Canadian Forest Products Industry. Strat. Manag. J. 2005, 26, 159-180. [CrossRef]

16. Denktas-Sakar, G.; Karatas-Cetin, C. Port Sustainability and Stakeholder Management in Supply Chains: A Framework on Resource Dependence Theory. Asian J. Shipp. Logist. 2012, 28, 301-319. [CrossRef]

17. De Langen, P.W. Stakeholders, Conflicting Interests and Governance in Port Clusters. Res. Transp. Econ. 2007, 17, 457-477. [CrossRef]

18. Van der Lugt, L.; de Langen, P. Port Authority Strategy: Beyond the Landlord, a Conceptual Approach. In Proceedings of the International Association of Maritime Economists (IAME) 2007 Conference, Athens, Greece, 4-6 July 2007.

19. Verhoeven, P. A Review of Port Authority Functions: Towards a Renaissance? Marit. Policy Manag. 2010, 37, 247-270. [CrossRef]

20. De Langen, P. The Performance of Seaport Clusters: A Framework to Analyze Cluster Performance and an Application to the Seaport Clusters of Durban, Rotterdam and the Lower Mississippi. Ph.D. Dissertation, Erasmus University Rotterdam, Rotterdam, The Netherlands, 2004.

21. De Langen, P. Governance in Seaport Clusters. Marit. Econ. Logist. 2004, 6, 141-156. [CrossRef]

22. Henesey, L.E.; Notteboom, T.E.; Davidsson, P. Agent-Based Simulation of Stakeholders Relations: An Approach to Sustainable Port Terminal Management. Available online: https://www.researchgate.net/publication/244452451_Agent-based_simulation_ of_stakeholders_relations_An_approach_to_sustainable_port_terminal_management (accessed on 3 April 2020).

23. Cahoon, S. Marketing Communications for Seaports: A Matter of Survival and Growth. Marit. Policy Manag. 2007, 34, 151-168. [CrossRef]

24. Parola, F.; Satta, G.; Penco, L.; Profumo, G. Emerging Port Authority Communication Strategies: Assessing the Determinants of Disclosure in the Annual Report. Res. Transp. Bus. Manag. 2013, 8, 134-147. [CrossRef]

25. Lam, J.S.L.; Voorde, E. Green Port Strategy for Sustainable Growth and Development. In Proceedings of the International Forum on Shipping, Ports and Airports (IFSPA): Transport Logistics for Sustainable Growth at a New Level; Yip, T.L., Fu, X., Ng, A.K.Y., Eds.; The Hong Kong Polytechnic University: Hong Kong, China, 2012.

26. Dare, M.; Schirmer, J.; Vanclay, F. Community Engagement and Social Licence to Operate. Impact Assess. Proj. Apprais. 2014, 32, 188-197. [CrossRef]

27. Vanclay, F.; Esteves, A.M.; Aucamp, I.; Daniel, F. Social Impact Assessment: Guidance for Assessing and Managing the Social Impacts of Projects. Available online: https://www.iaia.org/uploads/pdf/SIA_Guidance_Document_IAIA.pdf (accessed on 4 April 2020).

28. Voyer, D.M.; van Leeuwen, D.J. 'Social License to Operate' in the Blue Economy. Resour. Policy 2019, 62, 102-113. [CrossRef]

29. Peloza, J.; Loock, M.; Cerruti, J.; Muyot, M. Sustainability: How Stakeholder Perceptions Differ from Corporate Reality. Calif. Manag. Rev. 2012, 55, 74-97. [CrossRef] 
30. Dooms, M. Stakeholder Management for Port Sustainability. In Green Ports; Elsevier: Amsterdam, The Netherlands, 2019; pp. 63-84, ISBN 978-0-12-814054-3.

31. Brooks, M.R.; Pallis, A.A. Assessing Port Governance Models: Process and Performance Components. Marit. Policy Manag. 2008, 35, 411-432. [CrossRef]

32. Parola, F.; Pallis, A.A.; Risitano, M.; Ferretti, M. Marketing Strategies of Port Authorities: A Multi-Dimensional Theorisation. Transp. Res. Part Policy Pract. 2018, 111, 199-212. [CrossRef]

33. Deforche, J.; Loots, I.; Bergmans, A.; Vandermoere, F. Belevingsonderzoek Haven van Antwerpen: Hinderbeleving, Participatie En Betrokkenheid; Universiteit Antwerpen: Antwerpen, Belgium, 2013.

34. Thomson, I.; Boutilier, R.G. Social licence to operate. In SME Mining Engineering Handbook; Darling, P., Ed.; Society for Mining, Metallurgy and Exploration Inc.: Littleton, Colorado, 2011; pp. 1779-1796.

35. Moffat, K.; Lacey, J.; Zhang, A.; Leipold, S. The Social Licence to Operate: A Critical Review. Forestry 2016, 89, 477-488. [CrossRef]

36. Joyce, S.; Thomson, I. Earning a Social Licence to Operate: Social Acceptability and Resource Development in Latin America. Can. Min. Metall. Bull. 2000, 93, 49-53.

37. Boutilier, R.G. Frequently Asked Questions about the Social Licence to Operate. Impact Assess. Proj. Apprais. 2014, 32, 263-272. [CrossRef]

38. Boutilier, R.G. A Measure of the Social License to Operate for Infrastructure and Extractive Projects. SSRN Electron. J. 2017. [CrossRef]

39. Cullen-Knox, C.; Haward, M.; Jabour, J.; Ogier, E.; Tracey, S.R. The Social Licence to Operate and Its Role in Marine Governance: Insights from Australia. Mar. Policy 2017, 79, 70-77. [CrossRef]

40. Kelly, R.; Pecl, G.T.; Fleming, A. Social Licence in the Marine Sector: A Review of Understanding and Application. Mar. Policy 2017, 81, 21-28. [CrossRef]

41. Kelly, R.; Fleming, A.; Mackay, M.; García, C.; Pecl, G.T. Social Licence for Marine Protected Areas. Mar. Policy 2020, 115, 103782. [CrossRef]

42. Ircha, M. Social Licence for Ports. Available online: https://ctrf.ca/wp-content/uploads/2014/07/18IrchaSOCIALLICENSEFORPORTS. pdf (accessed on 6 April 2020).

43. Thomson, I.; Joyce, S. The Social Licence to Operate: What It Is and Why Does It Seem so Difficult to Obtain? Prospectors \& Developers Association of Canada Convention: Toronto, ON, Canada, 2008.

44. Thomson, I.; Boutilier, R.G. Modelling and Measuring the Social License to Operate: Fruits of A Dialogue between Theory and Practice. Available online: https://socialicense.com/publications/Modelling\%20and\%20Measuring\%20the\%20SLO.pdf (accessed on 7 April 2020).

45. Walker, T.R. Green Marine: An Environmental Program to Establish Sustainability in Marine Transportation. Mar. Pollut. Bull. 2016, 105, 199-207. [CrossRef]

46. Brick, J.; Kalton, G. Handling Missing Data in Survey Research. Stat. Methods Med. Res. 1996, 5, 215-238. [CrossRef] [PubMed]

47. Little, R.J.A.; Rubin, D.B. The Analysis of Social Science Data with Missing Values. Sociol. Methods Res. 1989, 18, 292-326. [CrossRef]

48. Stumpf, S.A. A Note on Handling Missing Data. J. Manag. 1978, 4, 65-73. [CrossRef]

49. Buhi, E.; Goodson, P.; Neilands, T. Out of Sight, Not Out of Mind: Strategies for Handling Missing Data. Am. J. Health Behav. 2008, 32. [CrossRef]

50. Rässler, S.; Riphahn, R.T. Survey Item Nonresponse and its Treatment. In Modern Econometric Analysis; Hübler, O., Frohn, J., Eds.; Springer: Berlin/Heidelberg, Germany, 2006; pp. 215-230. ISBN 978-3-540-32692-2.

51. Rowe, G.; Frewer, L.J. A Typology of Public Engagement Mechanisms. Sci. Technol. Hum. Values 2005, 30, 251-290. [CrossRef]

52. Rowe, G.; Marsh, R.; Frewer, L.J. Evaluation of a Deliberative Conference. Sci. Technol. Hum. Values 2004, 29, 88-121. [CrossRef]

53. Webler, T. "Right" Discourse in Citizen Participation: An Evaluative Yardstick. In Fairness and Competence in Citizen Participation; Renn, O., Webler, T., Wiedemann, P., Eds.; Springer: Dordrecht, the Netherlands, 1995; pp. 35-86, ISBN 978-0-7923-3518-4.

54. Moffat, K.; Zhang, A. The Paths to Social Licence to Operate: An Integrative Model Explaining Community Acceptance of Mining. Resour. Policy 2014, 39, 61-70. [CrossRef]

55. Dunn, K. Interviewing. In Qualitative Research Methods in Human Geography; Hay, I., Ed.; Oxford University Press: Melbourne, Australia, 2005; pp. 79-105.

56. Darbra, R.M.; Pittam, N.; Royston, K.A.; Darbra, J.P.; Journee, H. Survey on Environmental Monitoring Requirements of European Ports. J. Environ. Manag. 2009, 90, 1396-1403. [CrossRef] [PubMed]

57. Brooks, M.R. Good Governance and Ports as Tools of Economic Development: Are They Compatible. In World Shipping and Port Development; Tae-Woo Lee, P., Cullinane, K., Eds.; Palgrave MacMillan: Basingstoke, UK; New York, NY, USA, $2005 ;$ pp. 104-124.

58. Geerts, M.; Dooms, M. Sustainability Reporting for Inland Port Managing Bodies: A Stakeholder-Based View on Materiality. Sustainability 2020, 12, 1726. [CrossRef]

59. Black, L. The Social License to Operate: Your Management Framework for Complex Times; Do Sustainability: London, UK, 2013. 